\title{
Announcement of European Network for Mental Service of Evaluation (ENMESH)
}

In collaboration with the European Office of the World Health Organization, a European Network for Mental Service Evaluation (ENMESH) is now being established. Active researchers in the field are invited to request a registration form to join the network from Dr Aart Schene, (ENMESH Secretary), Associate Professor of Psychiatry, Academisch Medisch Centrum, Polikliniek Psychiatrie, Meibergdreef 9, 1105 AZ, Amsterdam (ZO), The Netherlands. 
Psychological Medicine, 1993, 23. Copyright (C) Cambridge University Press

\section{ERRATUM}

Buchanan, A. 'A two year prospective study of treatment compliance in schizophrenia' (Vol. 22, 787-797).

In Table 5 on page 793, the column headings reading from left to right should be: 'Compliance'; 'No tremor (\%)'; and 'Tremor (\%)'. 
PAPERS Papers for publication should be addressed to the Editor, Professor Michael Shepherd, Institute of Psychiatry, De Crespigny Park, Denmark Hill, London SE5 8AF. Contributors should send at least three copies of the text, tables and figures. Copies other than the first may be xeroxed. In addition to longer articles, the Editor is prepared to accept preliminary and brief communications of between 1500 and 2500 words.

Submission of a paper will be held to imply that it contains original work that has not been previously published and that it is not being submitted for publication elsewhere.

Manuscripts must be typewritten on one side of the paper in double-spacing with wide margins throughout, including references and notes, and consecutively numbered. The following information must be given on the first page (title sheet): (1) title and short title for running head (not more than 60 characters): (2) authors' names, and (3) department in which work was done. A short synopsis of about half an A4 page double-spaced must be provided at the beginning of each article. The name of an author to whom correspondence should be sent must be indicated and a full postal address given in the footnote. Any acknowledgements should be placed at the end of the text (before the Reference section).

Contributors should note the following:

1. Italic type should be indicated by underlining and bold type by wavy underlining (italic and bold typefaces should not be used even if they are available)

2. S.I. units should be used throughout in text, figures and tables

3. Authors should spell out in full any abbreviations used in their manuscripts.

4. Foreign quotations and phrases should be followed by a translation.

5. If necessary, guidelines for statistical presentation may be found in: Altman, D. G., Gore, S. M., Gardner, M. J. \& Pocock, S. J. (1983). Statistical guidelines for contributors to medical journals. British Medical Journal 286, 1489-1493.

REFERENCES (1) The Harvard (author-date) system should be used in the text and a complete list of References cited given at the end of the article. In a text citation of a work by more than two authors cite the first author's name followed by et al. (but the names of all of the authors should be given in the References section). Where several references are cited together they should be listed in rising date order. (2) The References section should be typed in alphabetical order on a separate sheet. Examples follow:

Brown, G. W. (1974). Meaning, measurement and stress of life events. In Stressful Life Events:

Their Nature and Effects (ed. B. S. Dohrenwend and B. P. Dohrenwend), pp. 217-244. John Wiley: New York.

Brown, J. (1970). Psychiatric Research. Smith: Glasgow.

Brown, J., Williams, E. \& Wright, H. (1970). Treatment of heroin addiction. Psychological Medicine 1, 134-136.

Journal titles should always be given in full.

FIGURES AND TABLES Only essential figures and tables should be included. Photographs Unmounted photographs on glossy paper should be provided. Magnification scales, if necessary, should be lettered on these. Where possible, prints should be trimmed to column width (i.e. 70 $\mathrm{mm}$ ). Diagrams These should not be included in the text and should be submitted in a form suitable for direct reproduction (the printed version will normally be reduced to $70 \mathrm{~mm}$ wide). Lettering should be in either Letraset or stencil, and care should be taken that lettering and symbols are of comparable size. All photographs, graphs, and diagrams should be referred to as figures and should be numbered consecutively in arabic numerals. Ensure that the figure number is marked on the back of the photograph or artwork together with the name of the author and paper title. Captions for figures should be typed double-spaced on separate sheets. Tables Tables should be numbered consecutively in the text in arabic numerals and each typed on a separate sheet after the References section. Titles should be typed above the table.

PROOFS AND OFFPRINTS Page proofs will be sent to the author indicated on the title page. Corrections other than to printer's errors may be charged to the author. Fifty offprints of each paper are supplied free; additional offprints are available according to a scale of charges if they are ordered when the proof is returned. 


\section{Psychological Medicine}

Volume 23 Number 1 February 1993

\section{CONTENTS}

\section{Editorials}

Cognitive neuropsychiatry? A. S. DAvID

The biology of autism A. J. BaILEY

Parasuicide: features of repetition and the implications for intervention L. APPLEBY \& R. WARNer

\section{Original Articles}

Sno, H. N. \& Draaisma, D. An early Dutch study of déja $v u$ experiences

Gill, M., McGuffin, P., Parfitr, E., Mant, R., Asherson, P., Collier, D., Vallada, H., Powell, J., Shaikh, S., Taylor, C., Sargeant, M., Clements, A., Nanko, S., Takazawa, N., Llewellyn, D., Williams, J., Whatley, S., Murray, R. \& OWen, M. A linkage study of schizophrenia with DNA markers from the long arm of chromosome 11

Woodruff, P. W. R., Pearlson, G. D., Geer, M. J., BARTA, P. E. \& Chilcoat, H. D. A computerized magnetic resonance imaging study of corpus callosum morphology in schizophrenia

45

Katona, C. L. E., Healy, D., Paykel, E. S., Theodorou, A. E., Lawrence, K. M., Whitehouse, A., White, B. \& Horton, R. W. Growth hormone and physiological responses to clonidine in depression

Grossi, D., Becker, J. T., Smith, C. \& Trojano, L. Memory for visuospatial patterns in Alzheimer's disease

Goldberg, T. E., Torrey, E. F., Gold, J. M., Ragland, J. D., Bigelow, L. B. \& Weinberger, D. R. Learning and memory in monozygotic twins discordant for schizophrenia

Channon, S., Baker, J. E. \& Robertson, M. M. Working memory in clinical depression: an experimental study

GrUZELIER, J. \& WARREN, K. Neuropsychological evidence of reductions on left frontal tests with hypnosis

Koponen, H. J. \& Riekkinen, P. J. A prospective study of delirium in elderly patients admitted to a psychiatric hospital

Denollet, J. Emotional distress and fatigue in coronary heart disease: the Global Mood Scale (GMS) 111

BuCHANAN, A. Acting on delusion: a review 123

Mackinnon, A., Henderson, A. S. \& Andrews, G. Parental 'affectionless control' as an antecedent to adult depression: a risk factor refined

135

Brown, G. W. \& Harris, T. O. Aetiology of anxiety and depressive disorders in an inner-city population. 1. Early adversity

Brown, G. W., Harris, T. O. \& Eales, M. J. Aetiology of anxiety and depressive disorders in an inner-city population. 2. Comorbidity and adversity
Van Hemert, A. M., Hengeveld, M. W., Bolk, J. H., Rooumans, H. G. M. \& Vandenbroucke, J. P. Psychiatric disorders in relation to medical illness among patients of a general medical out-patient clinic $\quad 167$

RatHNer, G. \& Messner, K. Detection of eating disorders in a small rural town: an epidemiological study

Goldberg, D. P., Jenkins, L., Millar, T. \& Faragher, E. B. The ability of trainee general practitioners to identify psychological distress among their patients 185

DowdNey, L., Rogers, C. \& DunN, G. Influences upon attendance at out-patient facilities - the contribution of linear-logistic modelling

Allen, H., Baigent, B., Kent, A. \& Bolton, J. Rehabilitation and staffing levels in a 'new look' hospital-hostel

Lindeboom, J., Horst, R. T., Hooyer, C., Dinkgreve, M. \& JONKER, C. Some psychometric properties of the CAMCOG

\section{Preliminary Communications}

Specific cognitive flexibility rehabilitation in schizophrenia A. Delahunty, R. Morice \& B. Frost

The role of the practice nurse in the management of depression in general practice: treatment adherence to antidepressant medication G. WILKINSON, P. ALLEN, E. Marshall, J. Walker, W. Browne \& A. H. ManN

\section{Research Report}

The Research Unit of the Servizio di Psicologia Medica at the Institute of Psychiatry of the University of Verona, 1980-1991 M. TANSELlA

\section{Book Reviews}

Medical Journals and Medical Knowledge: Historical Essays J. L. Crammer 249

The Cognitive Brain J. R. SMYTHIES 250

Exploring Brain Functional Anatomy with Positron Tomography. Ciba Foundation Symposium 163 P. F. LIDDLE

Schizophrenia: Manifestations, Incidence and Course in Different Cultures. WHO Ten-Country Study. Psychological Medicine Monograph Supplement 20 E. C. JOHNSTONE

Short Reviews

Psychiatry in the 1890 s

American Journal of Psychiatry Contents OctoberDecember 1992

269

Journal of Nervous and Mental Disease Contents JulySeptember 1992

The journal is listed in the major relevant abstracting and indexing services worldwide, including Current Contents, Excerpta Medica and Psychological Abstracts 